\title{
Metaplastic Breast Carcinoma with Unusual Presentation: Review of Three Cases
}

\author{
M. Asunción Fernández Pérez ${ }^{a} \quad$ Isabel Viqueira Rodriguez ${ }^{b} \quad$ Alberto Tello Royloa $^{a}$ \\ Javier Martínez Guisasola ${ }^{a}$
}



${ }^{\mathrm{b}}$ Department of Pathology, University Hospital Burgos, Spain

\section{Established Facts}

- Metaplastic breast carcinoma is an uncommon type of breast cancer that usually appears as a large, fast growing breast lump.

\section{Novel Insights}

- Metaplastic breast carcinoma may present unusually as a non-palpable lump.

\section{Keywords}

Breast cancer - Metaplastic carcinoma .

Clinical presentation

\section{Summary}

Background: Metaplastic breast carcinoma is an uncommon type of breast cancer that usually appears as a large, fast growing breast lump. Case Report: We report 3 cases of metaplastic breast carcinoma presented at our clinic in 2014. The mean age at diagnosis was 67.3 years. 1 patient presented with a fast growing, large mass detected by herself. However, in the other 2 patients, the nodule was approximately $1.5 \mathrm{~cm}$ in size, not fast growing, and was detected on mammography. All 3 patients were treated surgically (2 lumpectomies and 1 mastectomy), with the final pathology of metaplastic carcinoma with chondroid mesenchymal differentiation in 2 cases and metaplastic carcinoma with myoepithelial differentiation in the 3rd case. The patients are still under adjuvant therapy. Conclusions: Metaplastic breast carcinoma may present unusually as a non-palpable lump. This entity must be considered in any breast lump.

(C) 2015 S. Karger GmbH, Freiburg

\section{Introduction}

The metaplastic breast carcinoma is a rare malignancy with an incidence of $5 \%$ of all breast tumors $[1,2]$. It originates from a change in the differentiation of epithelial metaplastic breast tissue cells to squamous cell, spindle cell and/or mesenchymal appearance [3].

The metaplastic component can be benign or malignant. The differentiation degree and proportion of the elements shown in these tumors are highly variable and are visualized using immunohistochemistry and structural analysis [4].

From the pathological point of view, the latest World Health Organization (WHO) classification [3] included the following carcinomas within this group of neoplasms: adenosquamous carcinoma of low-grade fibromatosis type; metaplastic carcinoma; squamous cell carcinoma; and spindle cell carcinoma with chondroid mesenchymal, bone, or other mesenchymal tissue differentiation. In this latest ranking, the myoepithelial carcinoma was newly included within the metaplastic carcinomas [3].

The clinical, pathologic, and imaging diagnosis is complex. It is important to make a proper differential diagnosis since this determines the type of treatment to apply and the prognosis of the patient $[4,5]$.

\section{KARGER \\ Fax +497614520714

\section{() 2015 S. Karger GmbH, Freiburg}

$1661-3791 / 15 / 0106-0404 \$ 39.50 / 0$
M. Asunción Fernández Pérez, MD

Department of Obstetrics and Gynecology University Hospital Burgos

Avenida Islas Baleares 3, 09006 Burgos, Spain asferper@gmail.com 
Due to limited cases in the literature, there is no general consensus on the diagnosis and treatment, and it is difficult to draw definitive conclusions $[4,5]$, especially when making decisions about treatment $[6,7]$. Most often, complete removal of the lesion is indicated and the definitive diagnosis is deferred to after histological study [8].

We present a comparison of the 3 cases that have occurred in our hospital in 2014, describing the most representative differences.

\section{Case Report}

In 2014, at the University Hospital of Burgos, 3 cases of metaplastic breast carcinoma were diagnosed and treated.

A detailed medical history with personal and family history was taken, and examination of both breasts reflecting the clinical classification was performed in all 3 patients. As complementary tests, mammography and ultrasoundguided breast biopsy (UGB), magnetic resonance imaging (MRI), blood count, biochemistry including liver function, tumor markers (carcinoembryonic antigen (CEA), cancer antigen (CA) 15.3), bone scan, abdominal ultrasound, and thorax radiography were performed in each case. All women were treated surgically. All these data are summarized in table 1.

The histological diagnosis in 2 of the patients was metaplastic carcinoma with chondroid mesenchymal differentiation, and in the 3rd case, it was metaplastic carcinoma with myoepithelial differentiation.

Institutional review board (IRB) approval was obtained and the patients provided their oral consent.

\section{Discussion}

Metaplastic breast carcinoma is a rare tumor (5\% malignancies) $[6,7]$, and when considering only the mesenchymal metaplastic carcinomas with differentiation, they represent $1 \%$ of the incidence of invasive breast carcinoma [3]. The true incidence is unknown because sometimes solitary loci were found that were not reflected in the pathology reports $[8,9]$.

Its nomenclature is also problematic because it has received different names throughout history and different authors have referred to this group of neoplasms using different terms, including carcinosarcoma, sarcomatoid carcinoma, carcinoma with pseudosarcomatous metaplasia, carcinoma with pseudosarcomatous stroma, carcinoma producer matrix, fusiform carcinoma, myoepithelial carcinoma, etc. $[3,5]$.

Metaplastic breast carcinoma most often affects women over 50 years of age, with an average age between 55 and 60 years [10-12].

The most common form of presentation is a palpable mass with rapid growth, which may begin in any quadrant and is usually well circumscribed. Involvement sometimes can reach a size that may lead to ulceration and fixing of the mass to the skin or chest wall [13]. Most often, the mass is detected by the patient herself and not in a screening program. There are reports of occurrence during pregnancy and of presentation as inflammatory carcinoma [14].

Neither mammograms nor breast ultrasound have provided specific images, but have demonstrated that the tumors are usually well circumscribed, generally without associated microcalcifications, but sometimes some portion of irregular contour appears upon mammography $[1,10]$.
Most breast tumors, both benign and malignant, have their origin in the mammary epithelium, which in the case of metaplastic carcinoma differentiates in other tissues (metaplasia). This differentiation is corroborated with the help of immunohistochemistry $[7,15]$. In the literature, the presence of squamous metaplasia is documented in $3.7 \%$ of invasive breast carcinomas, and heterologous metaplasia (usually bone or cartilage) at $0.2 \%$, although the latter is most frequently described when present $[16,17]$.

The metaplastic carcinomas according to the latest edition of the WHO classification (2012) can be distinguished as: purely epithelial carcinomas (adenosquamous carcinoma of low-grade fibromatosis type, metaplastic carcinoma, squamous cell carcinoma, spindle cell carcinoma), carcinomas in epithelial and mesenchymal elements (carcinoma with chondroid mesenchymal differentiation, marrow, or other mesenchymal differentiation), and myoepithelial carcinomas (which are included within the novel metaplastic carcinomas in the last WHO classification) [3].

Among the differential diagnoses, angiosarcoma, fibromatosis and mesenchymal spindle cell tumors, pleomorphic adenoma and pleomorphic carcinoma must be considered, which is useful for immunohistochemical studies allowing the demonstration that this group of neoplasms is of epithelial origin (cytokeratin $5 / 6$ positive) [3]. A proper diagnosis is important to establish the treatment and prognosis of the patient [16].

In a recent publication, metaplastic breast carcinoma has been associated with radial scars or complex sclerosing lesions, which are low-grade adenosquamous carcinomas. The precise nature of this association is unclear [18].

As for hormone receptors and prognostic markers, metaplastic carcinomas are triple negative in $90 \%$ of cases (estrogen receptor-, progesterone receptor-, and human epidermal growth factor receptor 2 (HER2)-negative cases) $[3,11]$. This is because they are often associated with poorly differentiated carcinomatous elements [13].

Axillary lymph node involvement is usually not given. These metastases have an incidence ranging from 6 to $25 \%[12,13,17]$. In non-metaplastic carcinomas, the frequency is higher (up to $47 \%$ ) but still lower than in sarcomas [19].

Although we do not have a long record of these cases to know the prognosis, we can determine that survival depends on the tumor size (factor of greatest risk, because in tumors above $5 \mathrm{~cm}$, the prognosis worsens), histology, the degree of tumor differentiation, the type and degree of the mesenchymal component, and the existence of axillary lymph node metastases and distant metastases.

Although there is no axillary involvement, there is a tendency to pulmonary metastases; so the tumor/node/metastasis (TNM) staging system is of little use as a prognostic factor. Most distant metastases occur through the blood, most frequently affecting the pleura, lungs, liver, and abdominal viscera $[2,8,12]$.

Survival at 5 years may vary from 38 to $65 \%[8,13,17]$, and over $50 \%$ of the local and/or distant recurrences appear before that time.

The treatment is surgical initially, with lymphadenectomy plus sentinel lymph node biopsy (SLNB) or radical mastectomy being the most common treatments, although as mentioned above the frequency of lymph node involvement is low but higher than in sarcomas. 
Table 1. Patient characteristics

\begin{tabular}{|c|c|c|c|}
\hline Patient & 1 & 2 & 3 \\
\hline Age, years & 48 & 98 & 56 \\
\hline $\begin{array}{l}\text { Reason for } \\
\quad \text { consultation }\end{array}$ & $\begin{array}{l}\text { painful nodule in the contralateral breast } \\
\text { during follow-up of a benign lump in the } \\
\text { affected breast }\end{array}$ & $\begin{array}{l}\text { fast-growing nodule in breast, enlarge- } \\
\text { ment accompanied by skin changes }\end{array}$ & $\begin{array}{l}\text { derived from the screening program due to a } \\
\text { BI-RADS } 3 \text { b } 1 \text { by nodule or mass }\end{array}$ \\
\hline $\begin{array}{l}\text { Clinical } \\
\quad \text { examination }\end{array}$ & $\begin{array}{l}\text { palpable nodule of } 1.5 \mathrm{~cm} \text {, regular, medium } \\
\text { consistency, located in the upper external } \\
\text { quadrant (already known); no tangible } \\
\text { lymphadenopathy }\end{array}$ & $\begin{array}{l}\text { increased breast size, tension; a nodule of } \\
\text { soft consistency is palpable and occupies } \\
\text { the entire breast, with signs of inflamma- } \\
\text { tion in the skin, which is thin and fragile } \\
\text { and has increased vascularity }\end{array}$ & $\begin{array}{l}\text { palpable nodule is hard, mobile, with well- } \\
\text { defined consistency; greater than } 1 \mathrm{~cm}\end{array}$ \\
\hline Mammography & $\begin{array}{l}\text { dense pattern, patchy, pseudonodular; } \\
\text { nodules in both breasts, } 1 \text { in the upper } \\
\text { external quadrant, retroareolar in affected } \\
\text { breast; multiple bilateral scattered microc- } \\
\text { alcifications with benign characteristics }\end{array}$ & not made & $\begin{array}{l}\text { mixed radiological pattern; predominance } \\
\text { of glandular tissue of medium density with } \\
\text { benign nodules; characteristics affect breast } \\
\text { where there is also a faint increase in density } \\
\text { in the upper external quadrant }\end{array}$ \\
\hline Ultrasound & $\begin{array}{l}\text { solid and polylobed nodule of } 22 \times 13 \\
\text { mm, located in the upper external quad- } \\
\text { rant, probably benign (BI-RADS 3); UGB } \\
\text { was performed because not described in } \\
\text { previous studies; bilateral simple cysts }\end{array}$ & $\begin{array}{l}\text { very heterogeneous pattern with destruc- } \\
\text { tion of normal ultrasound breast pattern; } \\
\text { mainly consisting of cystic areas having } \\
\text { multiple echoes inside low impedance } \\
\text { with anfractuous walls and increased } \\
\text { peripheral vasculature, affecting all } \\
\text { quadrants of the breast both in depth and } \\
\text { surface }\end{array}$ & $\begin{array}{l}\text { solid or mixed node of } 15 \times 13 \mathrm{~mm} \text { in af- } \\
\text { fected breast in the upper external quadrant, } \\
\text { very indefinite contours, with peripheral } \\
\text { vasculature, shadow interface and irregular } \\
\text { subsequent reinforcement; subcentimeter } \\
\text { simple bilateral cysts }\end{array}$ \\
\hline MRI & $\begin{array}{l}\text { cancerous nodule in union of upper quad- } \\
\text { rantsof } 23 \mathrm{~mm} \text {; no involvement of skin, } \\
\text { nipple or chest wall; ipsilateral axilla and } \\
\text { normal mammary chains; } 6 \text { MRI BI-RADS } \\
\text { unifocal }\end{array}$ & $\begin{array}{l}\text { MRI not indicated by the advanced age } \\
\text { of the patient and the indication of total } \\
\text { mastectomy simple }\end{array}$ & $\begin{array}{l}\text { single cancerous nodule of } 15 \mathrm{~mm} \text { in union } \\
\text { of upper quadrants; nipple, skin, chest wall } \\
\text { and ipsilateral axilla are normal; normal } \\
\text { mammary chain; } 6 \text { MRI BI-RADS unifocal }\end{array}$ \\
\hline $\begin{array}{l}\text { Hormonal factors } \\
\text { (estrogen and } \\
\text { progesterone) }\end{array}$ & negative & negative & $\begin{array}{l}\text { estrogen: weakly positive ( } 3 \%) \text {; progesterone: } \\
\text { negative }\end{array}$ \\
\hline $\begin{array}{r}\text { Prognostic } \\
\text { factors }\end{array}$ & $\begin{array}{l}\text { p53: positive } 60 \% \text {; HER2: negative; } \\
\text { Ki-67: positive } 40 \% \text {; CK-19: positive }\end{array}$ & $\begin{array}{l}\text { p53: positive } 10 \% \text {; HER2: negative; } \\
\text { Ki-67: positive } 40 \% \text {; CK19: negative }\end{array}$ & $\begin{array}{l}\text { p53: positive } 30 \% \text {; HER2: unknown ++; } \\
\text { Ki-67: positive } 50 \% \text {; CK19: negative }\end{array}$ \\
\hline $\begin{array}{l}\text { Surgical } \\
\text { treatment }\end{array}$ & lumpectomy + SLNB & total mastectomy simple & lumpectomy + SLNB \\
\hline Histopathology & $\begin{array}{l}\text { SLN: negative; lumpectomy: metaplastic } \\
\text { carcinoma with chondroid mesenchymal } \\
\text { differentiation; unifocal; poorly differen- } \\
\text { tiated, grade III; resection margins } \\
\text { respected; immunohistochemical study of } \\
\text { hormone receptors and prognostic factors } \\
\text { identical to the core needle biopsy }\end{array}$ & $\begin{array}{l}\text { metaplastic carcinoma with myoepithelial } \\
\text { differentiation with infiltration of all } \\
\text { breast quadrants; infiltration of skin and } \\
\text { nipple areola complex with neoplastic } \\
\text { cells; perineural infiltration without } \\
\text { apparent vascular invasion; extensive } \\
\text { necrosis }\end{array}$ & $\begin{array}{l}\text { sentinel node }(\times 2) \text { : negative; lumpectomy: } \\
\text { poorly differentiated infiltrating ductal carci- } \\
\text { noma, grade III, with focal component of } \\
\text { metaplastic carcinoma with chondroid } \\
\text { differentiation; preserved surgical margins; } \\
\text { immunohistochemical study of hormone } \\
\text { receptors and prognostic factors identical to } \\
\text { the core needle biopsy; no amplification of } \\
\text { the HER2/neu gene studied by SISH }\end{array}$ \\
\hline Stage & pT1c N0 (0/2 sn) M0 & pT3NxMx & pT1c pN0 (0/2 sn) M0 \\
\hline Adjuvant therapy & $\begin{array}{l}\text { adriamycin-adjuvant cyclophosphamide } \\
\text { every } 3 \text { weeks for } 4 \text { cycles followed by } \\
\text { taxol weekly for } 8 \text { weeks; after chemother- } \\
\text { apy } 3 \mathrm{D} \text { external radiotherapy is performed } \\
\text { at } 50 \mathrm{~Gy}+16 \mathrm{~Gy}\end{array}$ & $\begin{array}{l}\text { no adjuvant therapy is given due to the } \\
\text { advanced age of the patient }\end{array}$ & $\begin{array}{l}\text { adriamycin-adjuvant cyclophosphamide } \\
\text { every } 3 \text { weeks for } 4 \text { cycles followed by taxol } \\
\text { weekly for } 8 \text { weeks; after chemotherapy 3D } \\
\text { external radiotherapy is performed at } \\
39.9+13.3 \text { Gy }\end{array}$ \\
\hline
\end{tabular}

BI-RADS = Breast Imaging Report and Data System, UGB = ultrasound-guided breast biopsy, MRI = magnetic resonance imaging, HER2 = human epidermal growth factor receptor 2, CK = cytokeratin, $\mathrm{SLNB}=$ sentinel lymph node biopsy, SISH = silver in situ hybridization, 3D = 3-dimensional.

Due to the scarcity of case series, the utility of chemotherapy and radiotherapy could not be demonstrated, but the tendency is to treat these tumors as high-risk carcinomas, regardless of whether or not they present with axillary involvement [20].

\section{Disclosure Statement}

There are no conflicts of interest for all authors. 


\section{References}

1 Günhan-Bilgen I, Memis A, Emin Üstün E, Zekioglu O, Özdemir N: Metaplastic carcinoma of the breast clinical, mammographic, and sonographic findings with histopathologic correlation. AJR Am J Roentgenol 2002;178:1421-1425.

2 Park JM, Han BK, Moon WK, Choe YH, Ahn SH, Gong G: Metaplastic carcinoma of the breast: mammographic and sonographic findings. J Clin Ultrasound 2000;28:179-186.

3 World Health Organization (WHO): WHO Classification of Tumors of the Breast, ed 4. Geneva, WHO, 2012.

4 Massuet A, Fernández S, Rimola J, Andreu FJ, Tortajada L, Sentís M: Carcinoma metaplásico de mama: resonancia magnética y correlación radiopatológica. Radiología 2006;48:155-163.

5 Amillano Párraga K, Elorriaga Barandiaran K, Alberro Aduriz JA, Martín López A, Rezola Solaun R, Plazaola Alcibar A: Carcinoma metaplásico de mama. Revisión a propósito de un caso. Oncología (Barc.) 2004;27(9).

6 Kuo SH, Chen CL, Huang CS, Cheng AL: Metaplastic carcinoma of the breast: analysis of eight Asian patients with special emphasis on two unusual cases presenting with inflammatory-type breast cancer. Anticancer Res 2000;20:2219-2222.

7 Bellino R, Arisio R, D'Addato F, Attini R, Durando A, Danese S, Bertone E, Grio R, Massobrio M: Metaplastic breast carcinoma: pathology and clinical outcome. Anticancer Res 2003;23:669-673.
Moreno J, Urquijo E, González-Lopera S, Díez J, Burgos J, Luján S, Rodríguez-Escudero FJ: Carcinoma metaplásico de mama: estudio clínico-histológico de siete casos. Clín Invest Ginecol Obstet 2003;30:222231.

9 Smith DM, Rongaus VA, Wehmann TW, Agarwal PJ, Classen GJ: Metaplastic breast carcinoma. J Am Osteopath Assoc 1996;96:419-421.

10 Patterson SK, Tworek JA, Roubidoux MA, Helvie MA, Oberman HA: Metaplastic carcinoma of the breast: mammographic appearance with pathologic correlation. AJR Am J Roentgenol 1997;169:709-712.

11 Rayson D, Adjei AA, Suman VJ, Wold LE, Ingle JN: Metaplastic breast cancer: prognosis and response to systemic therapy. Ann Oncol 1999;10:413-419.

$>12$ Kurian KM, Al-Natussi A: Sarcomatoid/metaplastic carcinoma of the breast: a clinicopathological study of 12 cases. Histopathology 2002;40:58-64.

13 Wagotz ES, Deos PH, Norris HJ: Metaplastic carcinoma of the breast II. Spindle cell carcinoma. Hum Pathol 1989;20:732-740.

14 Johnson TL, Kini SR: Metaplastic breast carcinoma: a cytohistologic and clinical study of 10 cases. Diagn Cytopathol 1996;14:226-232.
5 Khan HN, Wyld L, Dunne B, Lee AH, Pinder SE, Evans AJ, et al.: Spindle cell carcinoma of the breast: a case series of a rare histological subtype. Eur J Surg Oncol 2003;29:600-603.

16 Fisher ER, Gregorio RM, Palekar AS, Paulson JD: Mucoepidermiod and squamous cell carcinomas of breast with reference to squamous metaplasia and giant cell tumors. Am J Surg Pathol 1984;7:15-27.

17 Kaufman MW, Marti JR, Gallager HS, Hoehn JL: Carcinoma of the breast with pseudosarcomatous metaplasia. Cancer 1984;53:1908-1917.

18 Denley H, Pinder SE, Tan PH, Sim CS, Brown R, Barker T, et al.: Metaplastic carcinoma of the breast arising within complex sclerosing lesion: a report of five cases. Histopathology 1999;35:1-13.

19 Catroppo JF, Lara JF: Metastatic metaplastic carcinoma of the breast (MCB): an uncharacteristic pattern of presentation with clinicopathologic correlation. Diagn Cytopathol 2001;25:285-291.

20 Goldhirsch A, Glick JH, Gelber RD, et al.: Meeting Highlights: International Consensus Panel on the Treatment of Primary Breast Cancer. J Clin Oncol 2001;19:3817-3827. 